\title{
Identification of risk factors affecting production of beekeeping farms and development of risk management strategies: A new approach
}

\author{
Koksal Karadas ${ }^{1 *}$, Avni Birinci ${ }^{2}$ \\ ${ }^{1}$ Igdir University, Agricultural Faculty, Department of Agricultural Economics, Igdir, Turkey. \\ ${ }^{2}$ Ataturk University, Agricultural Faculty, Department of Agricultural Economics, Erzurum, Turkey.
}

\begin{abstract}
The aim of this investigation was to determine risk factors affecting production of beekeeping farms in Igdir province of Turkey and to develop strategies in coping with these risks. Research was based on data collected through a questionnaire applied to 85 beekeeping farms registered to Igdir Beekeepers' Union according to exact counting method. Factor analysis was applied to collected data to identify risk factors and risk management strategies. Factor analysis was conducted under principle component extraction method and VARIMAX rotation. A stepwise regression analysis was used to reveal the relationship between each of four strategy factors and eight risk factors. As risks in procuring labor occur, farmers are more likely to adopt modern agricultural techniques and risk management strategies, such as registering to a cooperative, product insurance, contract farming, and cooperating with public bodies. Unfavorable security conditions and lack of proper bookkeeping in farms are more likely to lead to adoption of careful production and investment planning. As enterprise conditions get better or external conditions get worse, protecting the investment through disease-prevention and better marketing through getting more market information becomes important. Thus, thirteen applicable strategies are determined in the study. As a result, the approach developed in this research could be suggested for beekeepers in selecting necessary strategies against possible risk factors defined here for sustainable honey production and more income.
\end{abstract}

Key Words: apiculture, approach, factor analysis, production economics, uncertainty

\section{Introduction}

As an agricultural activity that may generate income all year long under suitable climate conditions, apiculture provides more advantages for producers when compared with other agricultural activities. It can be carried out easily with relatively low capital investment and provides a continuous cash flow into farm budgets since it generates income in a rather shorter period. About four million farmers can potentially perform beekeeping in Turkey who have insufficient capital for commercial agriculture. As an activity with no land-area requirements, apiculture can be considered as a compulsory activity for all Turkish farmers who possess an average of 6 ha of land area. Apiculture requires relatively less labor and may provide an extra source of income and employment in rural areas (Kizilaslan

Received: September 26, 2017

Accepted: November 20, 2017

*Corresponding author: kkaradas2002@gmail.com

Copyright (c) 2018 Sociedade Brasileira de Zootecnia. This is an Open Access article distributed under the terms of the Creative Commons Attribution License (http://creativecommons.org/licenses/by/4.0/), which permits unrestricted use, distribution, and reproduction in any medium, provided the original work is properly cited. and Kizilaslan, 2007; Uzundumlu et al., 2011; Engindeniz et al., 2014; Kadirhanogullari et al., 2016a).

Bee products such as honey, beeswax, pollen, royal jelly, and bee venom have a wide range of usage. Besides human nutrition, apicultural products can be used in conventional and traditional medicine (Ozcan and Al Juhaimi, 2015). Exports of apicultural products also contribute to the economies of countries. Beekeeping plays important role in plant reproduction, and honey bees play an important role in pollinating more than one-third of plants on the surface of the earth by means of pollination (Klein et al., 2007; Pohorecka et al., 2014).

According to FAO (2016), world honey production in 2014 was 1663798 tons, while honey yield per beehive was $22 \mathrm{~kg}$. Turkey has a great potential for being an apicultural powerhouse in the 21 st century, with its rich flora, ecological structure, and genetic diversity in bee material (Karahan and Karaca, 2016). A total of 83647 Turkish enterprises produce 103525 tons of honey, which is about $6.8 \%$ of honey produced in the world, with a yield of $14.7 \mathrm{~kg}$ per beehive (TUIK, 2016), which is lower than the world average. Due to the lack of sufficient production techniques and especially lack of quality queen bees, honey production of Turkey is far behind that of Europe, as well as its per capita 
honey consumption which is approximately $1 \mathrm{~kg}$ (Aksoy and Ozturk, 2012). Although with advantageous climatic conditions and rich flora for apicultural activities, honey yield of Igdir province - located in the farthest eastern part of the country neighboring Iran, Armenia, and Azerbaijan - is lower than the Turkish and the world average, with $12.3 \mathrm{~kg}$ per beehive. There are numerous risk factors in agricultural sector and risk management strategies for offsetting the effects of these factors (Tumer, 2011). There are economic, social, and natural risks that adversely affect apicultural activities and honey yield as well. In case of a lack of suitable production conditions, risk and uncertainties resulting from production, marketing, financing, technological, political, and climate conditions are more likely to be encountered. Due to the effects of risk and uncertainty components, fluctuations in yield and price cause differences in agricultural income from year to year (Birinci and Tumer, 2006).

One hundred and forty-one beekeepers in the Turkish TRA2 NUTSII region were surveyed in a study conducted by Sezgin and Kara (2011) to determine the factors affecting yield of beekeeping activities. The study revealed that possessing a beekeeper certificate, membership to a union, beekeeping being the sole source of livelihood, having Caucasian bees as production material, and the age of queen bee are significant factors affecting honey yield. Guney et al. (2016) employed Path Analysis on the data obtained from colonies in the Beekeping Research Center of the Department of Animal Science of the Faculty of Agriculture of Cukurova University to investigate direct and indirect effects of brood rearing area, flight activity, pollen collection, nectar collection, and cleaning power on honey yield. According to the findings of the study, brood rearing area has a direct and statistically significant impact on honey yield, while nectar collection behavior has the highest indirect effect. Karakaya and Kiziloglu (2015) conducted a regression analysis using data on the number of new and old hives, amount of honey produced, and number of enterprises to analyze the existing state of beekeeping in Bingol province of Eastern Anatolia, Turkey, which possesses very favorable conditions for beekeeping. The study concluded that number of new hives was found to have an important and significant effect on honey yield.

Uzundumlu et al. (2011) studied the socioeconomic structures of 63 beekeeping enterprises of Bingol province, selected for proportional sampling method, and applied regression analysis to determine factors affecting honey yield in the province, which has a high, but underutilized potential for beekeeping. The study revealed that beekeeping activities were mostly performed by farmers over middleage. Unfavorable climatic conditions and wintering losses were reported as important factors affecting production. Honey yield was found to be higher in enterprises with higher number of hives, members of cooperatives, and practicing migratory beekeeping.

Investigating the relationship between climate change and beekeeping, Sahin (2015) reported that beekeeping is affected by climate change and many related factors; however, impacts of these effects are limited. Aiming to identify risk factors affecting production in beekeeping enterprises in Ordu province and aversion strategies, Aksoy and Ozturk (2012) surveyed 110 beekeepers in Ordu, selected according to proportional sampling method, and performed factor analysis and cluster analysis on the obtained data. After grouping risk factors, two homogenous groups of farmers were identified via cluster analysis. "Security" was found to be the highest factor of importance in both groups of farmers.

In this context, determination of factors adversely influencing apiculture and developing risk management strategies that identify measures against restraining risk factors are very important for the increase of productivity, income, and production and promotion of apiculture. Hence, the objective of this study was to establish risk factors influencing beekeeping production in Igdir province of Turkey and to develop strategies in coping with these risk factors through a combination of explanatory factor analysis and stepwise regression analysis techniques as a new approach. The research tried to find answers to such questions as "Which risks are beekeepers prone to in their activities of production?" and "How do beekeepers take measures to minimize the effects of these risks?" We argue that farmers are not aware of the risks they face in beekeeping production, and, thus, they do not take any prevention measures. Therefore, the research hypotheses are stated as follows:

$\mathrm{H}_{0}$ : Farmers are not aware of risks and do not take precautionary strategies.

$\mathrm{H}_{1}$ : Farmers are aware of risks and take precautionary strategies.

There are a few studies on the risk factors and risk management strategies in beekeeping production in Turkey. Aksoy and Ozturk (2012) studied risk factors and management strategies in Ordu province of Turkey. Ozturk et al. (2005) studied factors affecting beekeeping through factor analysis method. Saner et al. (2011) investigated technical and economic aspects of organic honey production and found that marketing, organization, finding suitable location, and transportation are important factors affecting organic beekeeping. Our study is the first one utilizing factor analysis approach to determine risk factors and risk management strategies in Igdir province of Turkey. 


\section{Material and Methods}

In case the subjected population is small and achieving the required information is relatively easier and cheaper, it is better to use census method. If data gathered by census are meticulously compiled, it can reflect more reliable outcomes (Cicek and Erkan, 1996). The population of the study consisted of registered members of Igdir Beekeepers' Union. Igdir province includes well-known Agri Dagi - the same Ararat Mountain that is recognized as the location where Noah's Ark stopped and the birthplace of viticulture, when Noah himself planted a vineyard after the flood and made the wine according to the Bible. According to the records of The Ministry of Food, Agriculture and Animal Husbandry and Igdir Beekeepers' Union, there are 85 beekeeping farms, which have at least 20 beehives. In this study, the exact count of the integer method is used.

Beekeeping farms in Igdir have an average of 60 hives. Beekeeping farms are family farms, whose average size is 4.71 people per farm. Fifty-two percent of the entrepreneurs have primary-school diplomas, while approximately $7 \%$ are university graduates. Beekeepers have an average work experience of 20 years, and $92.9 \%$ have social security registration. Average annual income in beekeeping farms was US\$ 5346 in April 2015. Eightyseven percent of beekeepers have also another source of income (Kadirhanogullari et al., 2016b).

In the study, 25 risk factors affecting production of beekeeping enterprises in Igdir province were determined, considering the conditions of the region, as well as 13 strategies that may be applied to avoid or offset these risks.

Each item in the study had an ordinal variable structure ranging from 1 to 9. Twenty-five items regarding risk factors of beekeeping were given as follows: $\mathrm{K} 1$, changes in government policies on beekeeping; $\mathrm{K} 2$, changes in economic conditions of the country; K3, unfavorable climate conditions; $\mathrm{K} 4$, inability to fight diseases and pest control; $\mathrm{K} 5$, changes in product prices; $\mathrm{K} 6$, changes in yield; K7, changes in interest rates; $\mathrm{K} 8$, increasing debts; $\mathrm{K}$, losses incurred due to diseases and during wintering; $\mathrm{K} 10$, nutritional deficiency; K11, increases in input costs; $\mathrm{K} 12$, product losses due to theft; K13, losses stemming from attacks of wild animals (i.e. bears); K14, impact of environmental pollution; K15, health problems of keeper, family, or one of the workers; K16, lack of household labor force; K17, high wages of external labor force; K18, lack of external labor force; K19, lack of technical knowledge; K20, lack of technical equipment; K21, ineligibility to get bank loans; K22, not keeping accounting records; K23, lack of technical knowledge and consultancy related to agricultural activity; K24, insufficient marketing opportunities; K25, losses incurred due to storing conditions.

Thirteen items regarding risk management strategies of beekeeping were given as follows: L1, selling products in different seasons; L2, having information about the market; L3, working in a different sector/activity than beekeeping; L4, registering to a cooperative; L5, planning the expenses; L6, decreasing debts; L7, investing outside the enterprise; L8, using available resources optimally; L9, buying agricultural insurance policies; L10, fighting diseases and pest control; L11, engaging in contract farming; L12, cooperating with agricultural bodies; L13, keeping regular business records.

Risk factors (K; 25 items) and risk management strategies (L; 13 items) of beekeeping data sets in the questionnaire study were separately exposed to factor analysis by considering principal component extraction method and VARIMAX rotation. Factor analysis can be expressed in the following matrix form:

$$
\mathrm{Z}_{\mathrm{px} 1}=\lambda_{\mathrm{pxm}} \mathrm{F}_{\mathrm{mxl}}+\mathrm{E}_{\mathrm{px} 1} \text {, }
$$

in which $\mathrm{Z}$ is a px 1 vector of $\mathrm{K}$ and $\mathrm{L}$ variables, $\lambda$ is a pxm matrix on factor loadings, $\mathrm{F}$ is a $\mathrm{mx} 1$ vector of the extracted factors, and $\mathrm{E}$ is a px 1 vector of error factors.

In the application of the factor analysis, eigenvalues were used to produce a correlation matrix for each $\mathrm{K}$ and L. Varimax rotation was adopted for a more accurate interpretation of factor loads obtained by factor analysis. Factor loading is estimated as Pearson correlation coefficient between a variable and a factor. Factors whose eigenvalues were greater than unity were selected for determining the number of suitable factors. New latent uncorrelated factors were derived from $\mathrm{K}$ and $\mathrm{L}$ variables in the application of the factor analysis based on VARIMAX rotation and principal component extraction method. Use of latent uncorrelated factor variables is recommended (Leech et al., 2005) for definitely removing multicollinearity problems that can be encountered in multiple linear regression analysis technique.

Kaiser-Meyer-Olkin (KMO) measure of sampling adequacy and Bartlett's test of spherity criteria were used to test the suitability of factor analysis to the data sets used here. The KMO criterion ranging from 0 to 1 should be at least 0.6. Bartlett's test of spherity criterion tests null hypothesis on whether the correlation matrix is identity. For the factor analysis to be suitable to the evaluated data, the null hypothesis should be rejected.

The sorted rotated factor loads for risk factors $(\mathrm{K}=25$ items) and risk management strategies $(\mathrm{L}=13$ items) were used in the interpretation of factor analysis. Four factors (FSSTR1, modern agriculture and risk management; 
FSSTR 2, debt management and product diversification; FSSTR 3, marketing and fight against diseases and pests; FSSTR 4, working in a different sector or activity) were extracted from 13 items regarding risk management strategies, whereas eight factors (FSR1, macro conditions; FSR2, provision of external services; FSR3, climate and diseases; FSR4, indebtedness; FSR5, social and human capital; FSR6, enterprise conditions; FSR7, external factors; FSR8, security and accounting) were extracted from 25 items concerning risk factors.

In the new approach developed in the present study, each of the four factors extracted from risk strategies in the factor analysis was considered as a dependent variable in stepwise regression analysis and eight strategies on risk factors were employed as independent variables in the stepwise regression. Stepwise regression models obtained here were as follows:

Prediction equation Model P

$\mathrm{FSSTR} 1=0.238 \mathrm{FSR} 2 *+0.272 \mathrm{FSR} 6 * *$ P:0.003

FSSTR2 $=-0.325$ FSR $8 *+0.192$ FSR6 -0.162 FSR7 -0.159 FSR 1 P:0.002 FSSTR $3=-0.266$ FSR $8 * *+0.264$ FSR7 $* *$ +0.259 FSR $3 * *-0.238$ FSR6 $*+0.185$ FSR 1 P:0.000

FSSTR4 $=0.238$ FSR5 $*+0.202$ FSR $1 *$

$+0.190 \mathrm{FSR} 8-0.158 \mathrm{FSR} 3$

P:0.000

* $\mathrm{P}<0.05$; ** $\mathrm{P}<0.01$.

The factor analysis and stepwise regression analysis were carried out with statistical software IBM SPSS version 23 .

\section{Results}

Linear combination of factor score coefficients with $\mathrm{K}$ variables gives factor score value for each beekeeping enterprise in relation to any factor. There were eight factors within the $\mathrm{K}$ variables with eigenvalues greater than unity. In this respect, we described eight factors in the factor analysis specified by VARIMAX rotation and extracted by Principal Component method.

In the study, eight factors accounted for $69 \%$ of the variability in the data of risk factors affecting apicultural data (Table 1).

The communality values varied from 0.420 to 0.840 . For example, $84.0 \%$ of the variability in variable K4 were explained by eight factors specified in the factor analysis. The sorted rotated factor loading after VARIMAX rotation is described as Pearson correlation coefficient between a
Factor and a raw variable (each $\mathrm{K}$ variable). Factor 1 was positively correlated with variables K5 (0.868), K6 (0.751), $\mathrm{K} 1$ (0.564), and K2 (0.442) $(\mathrm{P}<0.01)$, meaning that K5, K6, $\mathrm{K} 1$, and $\mathrm{K} 2$ provided a much more significant contribution to the formation of Factor 1 compared with other $\mathrm{K}$ variables. Since factors K1, K2, K5, and K6 are the main factors determining the first factor, we can define them as macro conditions (FSR1). It could be said that K5, K6, $\mathrm{K} 1$, and $\mathrm{K} 2$ increased with increasing Factor 1 (Table 1). Similarly, K18, K17, and K10 were loaded on Factor 2. It is evident that Factor 2 increased with increasing variables K18, K17, and K10 in Factor analysis (Table 1) because these three variables [K18 (0.833), K17 (0.807), and K10 $(0.677)]$ were correlated positively with Factor $2(\mathrm{P}<0.01)$. We may think the second factor to be "Provision of external services" (FSR 2).

When Factor 3 taken into consideration, variables K4 (0.864) and $\mathrm{K} 3$ (0.843) contribute more variation to Factor 3 and, therefore, significant correlations between the variables and Factor 3 can be observed. The third factor may be considered as "Climate and diseases" (FSR3).

Results of the factor analysis revealed that there were positive Pearson correlation coefficients between pairs of variables of Factor $4-\mathrm{K} 7(0.873)$ and Factor $4-\mathrm{K} 8$ (0.817) $(\mathrm{P}<0.01)$. In other words, variables $\mathrm{K} 7$ and $\mathrm{K} 8$ in the study strongly loaded Factor 4 . The fourth factor may be considered as a "Indebtedness" (FSR4).

Factor 5 had high positive loadings on variables K15 (0.740), K16 (0.692), and K21 (0.530) in the questionnaire data set. The fifth factor can be considered as "Social and human capital" (FSR5).

Factor 6 was positively correlated with K14 (0.737), K20 (0.596), K19 (0.584), and K24 (0.466), respectively, but negatively correlated with K25 (-0.363). We may consider the sixth factor as "Enterprise conditions" (FSR6). However, K11 (0.693), K23 (0.637), and K9 (0.486) were major variables in the formation of Factor 7. It can be regarded as "External factors" (FSR7). Correspondingly, Factor 8 possessed a large positive loading on K13, K12, and K22. The eighth factor may be thought of as "Security and accounting" (FSR8).

Four factors accounted for $65.7 \%$ of the variability in the $\mathrm{L}$ variables. The communalities ranged from 0.465 to 0.845 (Table 2). For instance, the four factors derived from the factor analysis explained $72 \%$ of the variability in L13.

Factor 1 had high positive loadings on L13 (0.838), L4 (0.715), L9 (0.711), L1 (0.689), L11 (0.679), L12 (0.583), and L8 (0.526). The first factor may be defined 
Table 1 - Sorted rotated factor loadings and communalities for $\mathrm{K}$ variables



Table 2 - Sorted rotated factor loadings and communalities for L variables

\begin{tabular}{lccccc}
\hline Variable & Factor 1 & Factor 2 & Factor 3 & Factor 4 & Communality \\
\hline L13 & 0.838 & -0.072 & -0.098 & -0.050 & 0.720 \\
L4 & 0.715 & -0.274 & 0.095 & -0.061 & 0.600 \\
L9 & 0.711 & -0.175 & 0.082 & -0.142 & 0.563 \\
L1 & 0.689 & -0.246 & 0.178 & -0.225 & 0.617 \\
L11 & 0.679 & -0.200 & 0.062 & 0.242 & 0.563 \\
L12 & 0.583 & -0.568 & 0.085 & 0.174 & 0.700 \\
L8 & 0.526 & -0.132 & 0.406 & -0.078 & 0.465 \\
L7 & 0.152 & -0.853 & 0.002 & -0.197 & 0.789 \\
L6 & 0.215 & -0.834 & 0.173 & 0.135 & 0.790 \\
L5 & 0.425 & -0.556 & 0.136 & 0.009 & 0.508 \\
L2 & 0.038 & -0.219 & 0.779 & -0.211 & 0.701 \\
L10 & 0.095 & 0.026 & 0.745 & 0.338 & 0.679 \\
L3 & 0.122 & 0.007 & -0.024 & -0.911 & 0.845 \\
Variance & 3.5460 & 2.3329 & 1.4434 & 1.2174 & 8.5398 \\
\% Variance & 0.273 & 0.179 & 0.111 & 0.094 & 0.657 \\
\hline
\end{tabular}

as "Modern agriculture and risk management" (FSSTR1). However, Factor 2 was negatively correlated with variables L7 (-0.853), L6 (-0.834), and L5 (-0.556) in the survey, showing that factor 2 increased when reducing variables L7, L6, and L5. We might consider the second factor as "Debt management and product diversification" (FSSTR2).

Factor 3 had strong factor loading on variables L2 and L10 as the third factor had positive correlations with variables. The third factor may be described as "Marketing and fight against diseases and pests" (FSSTR3). Only L3 significantly contributed to the formation of Factor 4 as a result of very high and negative correlation of 0.911 . We might consider the fourth factor as "Working in a different sector or activity" (FSSTR4).

\section{Discussion}

According to Model 1 (FSSTR $1=0.238$ FSR2 $*+0.272$ FSR6**), there is a positive and significant relationship between latent variable FSR2 (Provision of external services) and risk variables $\mathrm{K} 18, \mathrm{~K} 17$, and $\mathrm{K} 10$, which are effective in the formation of FSR2. Latent variable FSR2 increases as importance given to these risk variables increase and, since there is a positive and significant relationship between FSR2 and latent variable FSSTR1 (Modern Agriculture and Risk Management), FSSTR1 also increases as FSR2 increases. Because there is a positive and significant relationship between latent variable FSSTR1 and strategy variables L13, L4, L9, L1, L11, L12, and L8 that contribute to the formation of FSSTR1, as FSSTR1 increases, importance is given to those strategy variables should increase as well. This means that, as importance of risk factors K17 (High wages of external labor force), K18 (lack of external labor force), and K10 (nutritional deficiency) increases, management strategies L12 (Cooperating with agricultural bodies), L4 (Registering to a cooperative), L9 (Buying agricultural insurance policies), 
L1 (Selling products in different seasons), L11 (Engaging in contract farming), L13 (Keeping regular business records), and L8 (Using available resources optimally) become important for the producers. In this way, the enterprise minimizes the loss risk by externally procuring those services or inputs which cannot be provided from within the enterprise with cost effectiveness, thereby increasing productivity and profitability of production.

In the same model, there is a positive and significant relationship between latent variable FSR6 (Enterprise conditions) and risk variables K14, K20, K19, and K24 that form FSR6. Latent variable FSR increases as the importance given to these risk variables increases. A negative and significant relationship between risk variable K25 and latent variable FSR6 means that, as importance of this variable increases, latent variable FSR6 decreases. Because of a positive and significant relationship between latent variables FSR6 and FSSTR1 (Modern agriculture and risk management), FSSTR1 increases as FSR6 increases. Since there is a positive and significant relationship between FSSTR1 and strategy variables L13, L4, L9, L1, L11, L12, and L8 forming FSSTR1, the importance given to these strategy variables should increase as FSSTR1 increases. In other words, as the importance of risk factors K14 (Impact of environmental pollution), K20 (Lack of technical equipment), K19 (Lack of technical knowledge), and K24 (Insufficient marketing opportunities) increases, management strategies L12 (Cooperating with agricultural bodies), L4 (Registering to a cooperative), L9 (Buying agricultural insurance policies), L1 (Selling products in different seasons), L11 (Engaging in contract farming), L13 (Keeping regular business records), and L8 (Using available resources optimally) become important. As enterprise conditions get better, implementation of modern agricultural techniques and risk management will become easier; therefore, the revenue of the enterprise will increase as a result of increases in yield. Moreover, adapting to changing business environment and planning of input use and marketing activities by the enterprises are important for sustainability of activities.

According to the second model (FSSTR2 $=-0.325$ FSR8* + 0.192 FSR6 - 0.162 FSR7 - 0.159 FSR1), there is a positive and significant relationship between latent variable FSR8 (Security and accounting) and risk variables $\mathrm{K} 13, \mathrm{~K} 12$, and $\mathrm{K} 22$, which are effective in the formation of this variable. As the importance given to these variables decreases, latent variable FSR8 also decreases. Since there is a positive and statistically significant relationship between FSR8 and latent variable FSSTR2 (Debt management and product diversification), FSSTR2 decreases as the importance of FSR8 decreases. Because there is a negative and significant relationship between FSSTR2 and strategy variables $\mathrm{L} 7, \mathrm{~L} 6$, and $\mathrm{L} 5$ that contribute to the formation of FSSTR2, the importance given to these variables should increase as FSSTR2 decreases. That is, if the importance given to risk factors K13 (Attacks by wild animals), K12 (Theft), and K22 (Keeping proper accounting records) decreases, management strategies L7 (Investing outside the enterprise), L6 (Decreasing debts), and L5 (Planning the expenses) must therefore become important for the producer. Here, because keeping proper books helps determining such data as the amount of inputs used, cost of these inputs, yield, and prices, the importance given to debt management decreases. In the same fashion, taking security measures decreases the importance of product diversification strategy as well. In short, providing a more hands-on approach in managing financial and security risks increase profitability of beekeeping activities.

The reason that FSR8 emerged as a significant factor is that beekeepers think that outside factors that they cannot control such as wild animals and thieves have more possibility of damaging their operation and property. This causes beekeepers to invest outside their enterprises to distribute risks and stay secure in cases of property and operational losses due to wild animal attacks and thefts. On the other hand, since a great majority of beekeepers have only primary school degrees, they are not comfortable with keeping records. Yet, they are also aware of the importance of keeping proper books, so they try to plan their expenses and repay their debts as much as they can. However, it is also interesting that, rather than diversifying products to distribute risks and diversify sources of income, the farmers prefer to increase security, implying that theft and animal attacks are presumed as the biggest risks to beekeeping operations rather than climate change or lack of modern techniques.

According to Model 3 (FSSTR3 $=-0.266$ FSR8** $+0.264 \mathrm{FSR}^{* *}+0.259 \mathrm{FSR}^{* *}-0.238 \mathrm{FSR}^{*}+0.185$ FSR1), there is a positive and significant relationship between latent variable FSR8 (Security and accounting) and risk variables $\mathrm{K} 13, \mathrm{~K} 12$, and $\mathrm{K} 22$, which are effective in the formation of this variable. As the importance given to these variables decreases, latent variable FSR8 also decreases. Since there is a negative and statistically significant relationship between FSR8 and FSSTR3 (Marketing and fight against diseases and pests), FSSTR3 increases as FSR8 decreases. Because there is a positive and significant relationship between latent variable FSSTR3 and variables L2 and L10 contributing to the formation of FSSTR3, importance given to L2 and L10 should increase 
as FSSTR3 increases. That is, if importance given to risk factors K13 (Attacks by wild animals), K12 (Theft), and K22 (Keeping proper accounting records) decreases, management strategies L2 (Having information about the market) and L10 (Fighting diseases and pest control) should gain importance. As security and risks increase, fighting diseases and pests and accessing market information become important to offset losses caused by these risks as soon as possible.

Again, this model displays the importance of risks of wild animal attacks and theft. As farmers feel secure regarding wild animal attacks and theft, activities regarding sales and quality of production, such as fighting diseases, become important.

In the same way, since there is a positive and significant relationship between latent variable FSR6 (Enterprise conditions) and risk variables K14, K20, K19, and $\mathrm{K} 24$, contributing to the formation of this variable, FSR6 decreases as importance given to K14, K20, K19, and K24 decreases. Moreover, there is a significant, but negative, relationship between FSR6 and risk variable $\mathrm{K} 25$, which means that when K25 increases in importance, FSR6 decreases. Since there is a negative and significant relationship between FSR6 and FSSTR3 (Marketing and Fight against diseases and pests), FSSTR3 increases as FSR6 decreases. Because of the positive and significant relationship between strategies L2 and L10 and FSSTR3, the importance of factors contributing to the occurrence of FSSTR3 should increase accordingly. This means that, as importance of risk factors K14 (Impact of environmental pollution), K20 (Lack of technical equipment), K19 (Lack of technical knowledge), and K24 (Insufficient marketing opportunities) decreases, management strategies L2 (Having information about the market) and L10 (Fighting diseases and pest control) should gain importance. This means that, as above-mentioned risks decrease in importance, preventing production losses through disease and pest control and evaluating the market for possible alternatives for profit become dominant strategies for the producer.

On the other hand, a positive and significant relationship was detected between latent variable FSR7 (External factors) and risk variables K11, K23, and K9, which are effective in the formation of FSR7. Variable FSR7 increases in parallel to the increase in the importance of these risk variables and, since there is a positive and significant relationship between latent variables FSR7 and FSSTR3 (Marketing and Fight against diseases and pests), FSSTR3 increases as FSR7 increases. Because of the positive and significant relationship between L2 and L10 strategies and FSSTR3, the importance of factors contributing to the occurrence of FSSTR 3 should also increase. Thus, as importance given to risk factors K11 (Increases in input costs), K23 (Lack of technical knowledge and consultancy related to agricultural activity), and K9 (Losses incurred due to diseases and during wintering) increases, management strategies L2 (Having information about the market) and L10 (Fighting diseases and pest control) should also gain importance.

On the other hand, a positive and significant relationship is detected between latent variable FSR3 (Climate and diseases) and risk variables $\mathrm{K} 4$ and $\mathrm{K} 3$, which are effective in the formation of FSR3. Variable FSR3 increases in parallel to the increase in the importance of these risk variables and, since there is a positive and significant relationship between latent variables FSR3 and FSSTR3 (Marketing and Fight against diseases and pests), FSSTR3 also increases as FSR7 increases. Because of the positive and significant relationship between strategies L2 and L10 and FSSTR3, the importance of factors contributing to the occurrence of FSSTR3 should also increase. This means that, as importance given to risk factors K4 (Inability to fight with diseases and pests control) and K3 (Unfavorable climate conditions) increases, importance of management strategies L2 (Having information about the market) and L10 (Fighting diseases and pest control) should increase as well. In addition to security measures and keeping proper books, improving enterprise conditions would decrease the possibility of occurrence of these risks; thus, marketing and fight against diseases and pest control strategies will become matters of lesser importance for the producer.

A positive and significant relationship in the fourth model $($ FSSTR $4=0.238$ FSR5 $*+0.202$ FSR $1+0.190$ FSR8 -0.158 FSR3) is determined between latent variable FSR5 (Social and human capital) and risk variables K15, K16, and K21, which contributed to the formation of FSR5. As these risk factors become less important, FSR5 decreases. Since there is a positive and significant relationship between latent variables FSR5 and FSSTR4 (Working in a different sector or activity), FSSTR4 increases as FSR5 increases. Since there is a negative and significant relationship between FSSTR4 and strategy variable L3 forming this latent variable, L3 should gain importance as FSSTR4 decreases. That is, as risk factors K15 (Health problems of keeper, family, or one of the workers), K16 (Lack of household labor force), and K21 (Ineligibility to get bank loans) lose importance, L3 (Working in a different sector/activity than beekeeping) becomes an important strategy (Figure 1). In economic terms, the producer tries to offset losses incurred by illness by substituting beekeeping earnings with earnings generated by employment in another sector. In case there are 


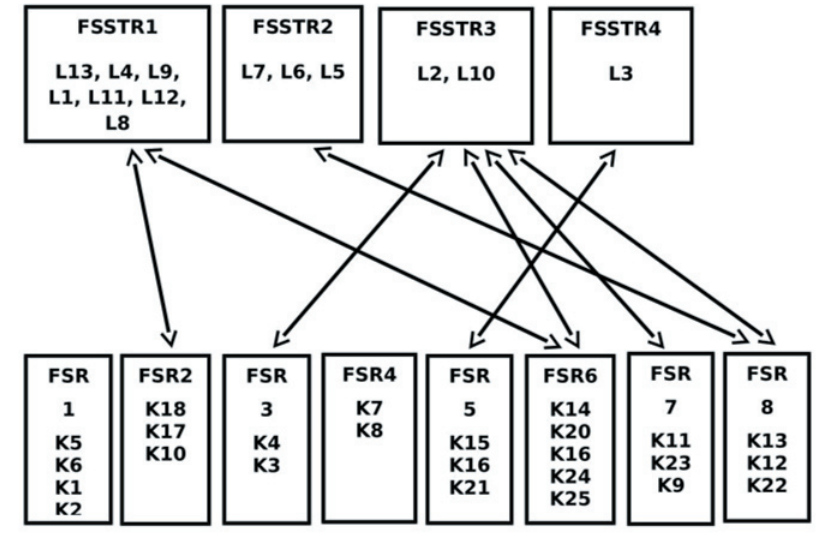

Figure 1 - Risk aversion strategies against risk factors in beekeeping.

no such health problems but the producer is denied bank credits, he/she tries to generate needed funds by working in other sectors or activities.

Determination of risk factors affecting beekeeping production is inevitable for more profitable beekeeping. Also, development of strategies against these risk factors is more likely to happen through a new statistical approach, a combination of explanatory factor analysis, and stepwise regression analysis techniques. This statistical approach suggested under investigation may be recommended for developing risk management strategies to obtain more beekeeping products.

\section{Conclusions}

This study deals with development of strategies against risk factors using a new statistical approach (e.g., the stepwise regression techniques) to determine risk management factors in bee production. The statistical technique used in this study can be recommended in the development of more effective risk management tools to obtain more beekeeping products. Thus, producers will develop the most suitable strategies against risk factors peculiar to their region, while honey and other bee products in each region can be better marketed by producers with sustainable production.

The results show that beekeepers would likely restructure their debts whenever possible, as a precaution against the costs resulting from wild animal attacks and thefts. Crop insurances will serve as more effective means for such precautionary events. In case of unfavorable climatic conditions and occurrence of pests and diseases, we recommend execution of support programs by local agricultural bodies, focusing on kind grants of sterile hives and bees. Yet, another important policy recommendation would be proper use of agricultural extension activities in the region to make beekeepers more aware of risks and uncertainty management practices such as keeping proper accounting records, adopting modern techniques, and management of crop diseases.

\section{Acknowledgments}

The authors acknowledge the scientific support of Associate Prof. Dr. Ecevit Eyduran in statistical analyses and express their sincere gratitude for his help.

\section{References}

Aksoy, A. and Ozturk, F. G. 2012. Aricilik Isletmelerinde Uretimi Etkileyen Faktorler; Ordu Ili Ornegi. 10. Ulusal Tarim Ekonomisi Kongresi, Konya. p.517-523.

Birinci, A. and Tumer, E. 2006. The attitudes of farmers towards agricultural insurance: The case of Erzurum, Turkey. Die Bodenkultur. Austrian Journal of Agricultural Research 57:49-55.

Cicek, A. and Erkan, O. 1996. Tarim ekonomisinde arastirma ve ornekleme yontemleri. Gaziosmanpasa Universitesi Ziraat Fakultesi Yayinlari No: 12, Ders Notlari Serisi No:6, p.45, Tokat.

Engindeniz, S.; Ucar, K. and Basaran, C. 2014. Izmir Ilinde Ariciligin ekonomik yonleri ve sorunlari. Tarim Ekonomisi Dergisi 20:113-120.

FAO - Food and Agriculture Organization of the United Nations. 2016. FAOSTAT. Available at: <http://www.fao.org/faostat/en/\#data/QL $>$. Accessed on: Dec. 10, 2016.

Guney, M. C.; Kumova, U. and Kayaalp, G. T. 2016. Bal verimini etkileyen bazi faktorlerin path analizi yontemi ile incelenmesi. Turk Tarim - Gida Bilim ve Teknoloji Dergisi 4:903-906.

Kadirhanogullari, I. H.; Karadas, K. and Kulekci, M. 2016a. Igdir llinde bal uretim maliyetinin belirlenmesi uzerine bir calisma. Igdir Universitesi Fen Bilimleri Enstitusu Dergisi 6:113-118.

Kadirhanogullari, I. H.; Karadas, K. and Kulekci, M. 2016b. Igdir Ili Aricilarinin sosyo-ekonomik durumu. Uludag Aricilik Dergisi 16:2-11.

Karahan, A. and Karaca, I. 2016. Adana ve Konya 1llerindeki aricilik faaliyetleri ve koloni kayiplari. Suleyman Demirel Universitesi Fen Bilimleri Enstitusu Dergisi 20:226-235.

Karakaya, E. and Kiziloglu, S. 2015. Bingol Ili Bal Uretimi. Igdir University Journal of the Institute of Science and Technology 5:25-31.

Klein, A. M.; Vaissiere, B. E.; Cane, J. H.; Steffan-Dewenter, I.; Cunningham, S. A.; Kremen, C. and Tscharntke, T. 2007. Importance of pollinators in changing landscapes for world crops. Proceedings of the Royal Society 274:303-313.

Kizilaslan, H. and Kizilaslan, N. 2007. Factors affecting honey production in apiculture in Turkey. Journal of Applied Sciences Research 3:983-987.

Leech, N. L.; Barrett, K. C. and Morgan, G. A. 2005. SPSS for intermediate statistics. Use and interpretation. Lawrence Erlbaum Associates, Publishers, Mahwah, New Jersey, London.

Ozcan, M. M. and Al Juhaimi, F. 2015. Honey as source of natural antioxidants. Journal of Apicultural Research 54:145-154. 
Ozturk, C.; Subasi, S.; Uysal, O.; Secer, A.; Alemdar, T. and Oren, M. N. 2005. Akdeniz bolgesinde Ariclik isletmelerinin teknik ve ekonomik yapisinin belirlenmesi. Tarimsal Ekonomi ve Politika Gelistirme Enstitusu. TEPGE Yayin No:254, Ankara.

Pohorecka, K.; Bober, A.; Skubida, M.; Zdańska, D. and Torój, K. 2014. A comparative study of environmental conditions, bee management and the epidemological situation in apiaries varying in the level of colony losse. Journal of Apicultural Science 58:107-132.

Sahin, V. 2015. The evaluation of the relationship between climate change and beekeeping based on students' views. The Journal of International Social Research 8:423-429.

Saner, G.; Yucel, B.; Yercan, M.; Karaturhan, B.; Engindeniz, S.; Cukur, F. and Kosoglu, M. 2011. Organik ve konvansiyonel bal uretiminin teknik ve ekonomik yonden gelistirilmesi ve alternatif pazar olanaklarinin saptanmasi uzerine bir arastirma: Izmir İli
Kemalpasa ilcesi ornegi. Tarimsal Ekonomi ve Politika Gelistirme Enstitusu. TEPGE Yayin No:195, Ankara.

Sezgin, A. and Kara, M. 2011. Aricilikta verim artisi uzerinde etkili olan faktorlerin belirlenmesine yonelik bir arastirma: Tra2 Bolgesi Ornegi. Harran Universitesi Ziraat Fakultesi Dergisi 15:31-38.

TUIK - Turkish Statistical Institute. 2016. Livestock statistics. Available at: $<$ https://biruni.tuik.gov.tr/hayvancilikapp/hayvancilik.zul $>$. Accessed on: Jan. 12, 2016.

Tumer, E. I. 2011. Erzurum, Erzincan ve Bayburt Illerinde (TRA 1 Bolgesi) ciftcilerin riske karsi tutumlari ve olasi sigorta primlerinin belirlenmesi uzerine bir arastirma, Ataturk Universitesi Fen Bilimleri Enstitusu, Tarim Ekonomisi Anabilim Dali, (Doktora Tezi), Erzurum.

Uzundumlu, A. S.; Aksoy, A. and Isik, H. B. 2011. Aricilik Isletmelerinde Mevcut Yapi ve Temel Sorunlar; Bingol Ili Ornegi. Ataturk Universitesi Ziraat Fakultesi Dergisi 42:49-55. 